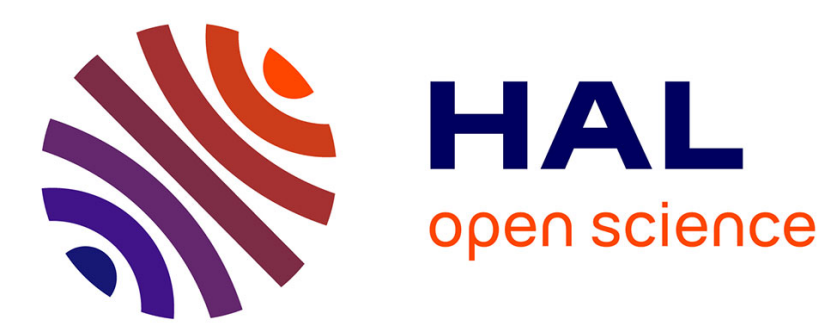

\title{
SPECTROSCOPY OF Ar-N2 MICROWAVE FLOWING POST-DISCHARGES
}

\author{
H. Malvos, André Ricard, M. Moisan, J. Hubert
}

\section{To cite this version:}

H. Malvos, André Ricard, M. Moisan, J. Hubert. SPECTROSCOPY OF Ar-N2 MICROWAVE FLOWING POST-DISCHARGES. Journal de Physique Colloques, 1990, 51 (C5), pp.C5-313-C5-319. 10.1051/jphyscol:1990538 . jpa-00230846

\section{HAL Id: jpa-00230846 https://hal.science/jpa-00230846}

Submitted on 1 Jan 1990

HAL is a multi-disciplinary open access archive for the deposit and dissemination of scientific research documents, whether they are published or not. The documents may come from teaching and research institutions in France or abroad, or from public or private research centers.
L'archive ouverte pluridisciplinaire HAL, est destinée au dépôt et à la diffusion de documents scientifiques de niveau recherche, publiés ou non, émanant des établissements d'enseignement et de recherche français ou étrangers, des laboratoires publics ou privés. 


\title{
SPECTROSCOPY OF Ar-N, MICROWAVE FLOWING POST-DISCHARGES
}

\author{
H. MALVOS, A. RICARD, M. MOISAN" and J. HUBERT* * \\ Laboratoire de Physique des Gaz et des Plasmas, Bât 212 université \\ Paris-Sud, CNRS, 91405 Orsay, France \\ "Département de physique, Université de Montréal, BP 620 , \\ Montréal H3C 3VI, Canada \\ * Département de Chimie, Université de Montréal, BP 620, Montréal H3C \\ 3V1, Canada
}

Résumế - La post-luminescence des dëcharges HF (13.6, 49.5 et 2450MHz) dans les mélanges $A r-N_{2}$ à 100 Torr a été étudiée par spectroscopie d'ēmission. Les processus de recombinaison $N+N+M_{2}$ et $N+C+M_{2}\left(M_{2}=A r-N_{2}\right)$ ont été caractêrisês. La densité des atomes de carbone dans la post-dêcharge a été déduite de la mesure des atomes d'azote par titration avec NO. Des rapports de densités $C / M_{2}$ aussi bas que $10^{-7}-10^{-8}$ ont étẻ trouvés dans des post-décharges à 100-200 Torr, avec des pourcentages élevés $(33-100 \%)$ de $\mathrm{N}_{2}$ dans $\mathrm{Ar}$.

Abstract - The flowing afterglow of 100 Torr Ar-N HF (13.6, 49.6 and $2450 \mathrm{MHz}$ ) discharges has been studied by emission spectroscopy. The $\mathrm{N}+\mathrm{N}+\mathrm{M}_{2}$ and $N+C+M_{2}\left(M_{2}=A r-N_{2}\right)$ recombination processes have been characterized. From $\mathrm{N}$ density measurements by NO titration, it has been deduced the $\mathrm{C}$ density in the post-discharges. $C / M_{2}$ density ratios as low as $10^{-7}-10^{-8}$ have been found in 100-200 Torr post-discharges with high percentages (33-100\%) of $\mathrm{N}_{2}$ in $\mathrm{Ar}$.

\section{1 - INTRODUCTION}

A growing interest of nitrogen flowing post-discharges recently appeared in the file of surface coating processes. For steel surface nitriding, thick coatings of $\mathrm{Fe}_{4} \mathrm{~N}$ (5-8 $\mu \mathrm{m}$ of thickness) have been obtained from $D C(1)$ and microwave (2) $N_{2}$ post-discharges.

In $\mathrm{N}_{2}$ flowing post-discharges, the $\mathrm{N}$ atoms are producing the Lewis-Rayleigh afterglow by the following three body reaction:

$$
\begin{gathered}
N+N+M_{2} \stackrel{k_{1}}{\rightarrow} N_{2}\left(B, V^{\prime}\right)+M_{2} \\
N_{2}\left(B, V^{\prime}\right) \rightarrow N_{2}\left(A, V^{\prime \prime}\right)+h v\left(1^{\text {st }}\right. \text { pos.) }
\end{gathered}
$$

where $k_{1}$ is the recombination rate and $M_{2}=A r-x N_{2}$ gas mixture.

It is the purpose of the present paper to study radiative emission in flowing afterglows of 100 Torr Ar-N $N_{2}$ HF posi-discharges. Such a gas pressure has been chosen to keep a constant power of about 100 watts in the plasma when $x$ is varying from 4 to $100 \%$. Higher $A r-N_{2}$ gas pressure plasmas, up to the atmospheric pressure, have been performed with such a low 100 watts power but for $x$ less than $10 \%$ in $2.45 \mathrm{GHz}$ microwave discharges (3). 


\section{2 - IHE EXPERIMENTAL SET UP}

The experimental set up is reproduced in Fig.1.

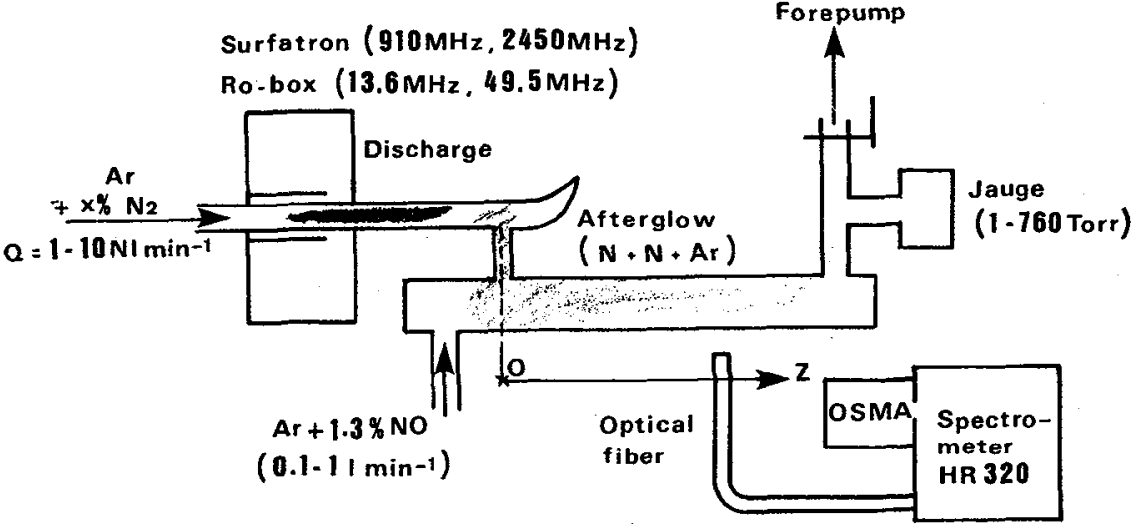

Fig.1 - the Ar- $\mathrm{N}_{2}$ microwave discharge and post-discharge set-up.

A surfatron (4) or a Ro-box (5) exciter is used to sustain an $A r-N_{2}$ discharge in a $4 \mathrm{~mm} I \mathrm{~d}, 6 \mathrm{~mm}$ Od and $10 \mathrm{~cm}$ long quartz tube. The two exciters have worked in the present experiment with $\mathrm{HF}$ frequencies of $910 \mathrm{MHz}, 2450 \mathrm{MHz}$ for the surfatron and 49.5MHz, 13.6 MHz for the Ro-box, respectively.

The flowing microwave discharge is related to a $10 \mathrm{~mm} I \mathrm{~d}, 12 \mathrm{~mm} 0 \mathrm{~d}, 10 \mathrm{~cm}$ long post-discharge quartz tube via a side-armed tube to separate the discharge and post-discharge glows. The post-discharge tube is connected to a forepump to maintain a mean gas pressure between 10 and 300 Torr and flow rates from 0.25 to 10 Nemin-1.

The visible plasma glow in the discharge tube is extending axially over a few centimeters for a microwave power of about 100 Watts, depending on gas pressure and flow rate. Downstream the discharge an homogeneous afterglow is extending along the $z$-axis (cf. Fig.1) in the post-discharge tube which is an electric field free region. Upstream the post discharge, an Ar-1.3\% NO gas mixture was introduced through a lateral gas inlet to determine the $N$ atom densities by NO titration (3).

The optical emission lines are detected perpendicularly to the axis of the post-discharge tube by means of a quartz optical fiber which is connected to a spectrometer, using an Optical Spectrometric Multichannel Analyser (OSMA) for the photon spectrum analysis. 


\section{3 - RADIATIVE EMISSION IN THE Ar - $\mathrm{N}_{2}$ FLOWING AFTERGLOW}

The $1^{\text {st }}$ pos. emission following the $\mathrm{N}$-atom recombination (reaction $\mathrm{i}$ ) has been detected along the axis of the post-discharge tube (cf. Fig.1). Spectrum of $\Delta V=4$ sequence is reproduced in Fig.2 for $A r-4 \% \quad N_{2}$ gas mixture at 90 Torr, 100 Watts, $Z=9 \mathrm{~cm}$ in the post-discharge.

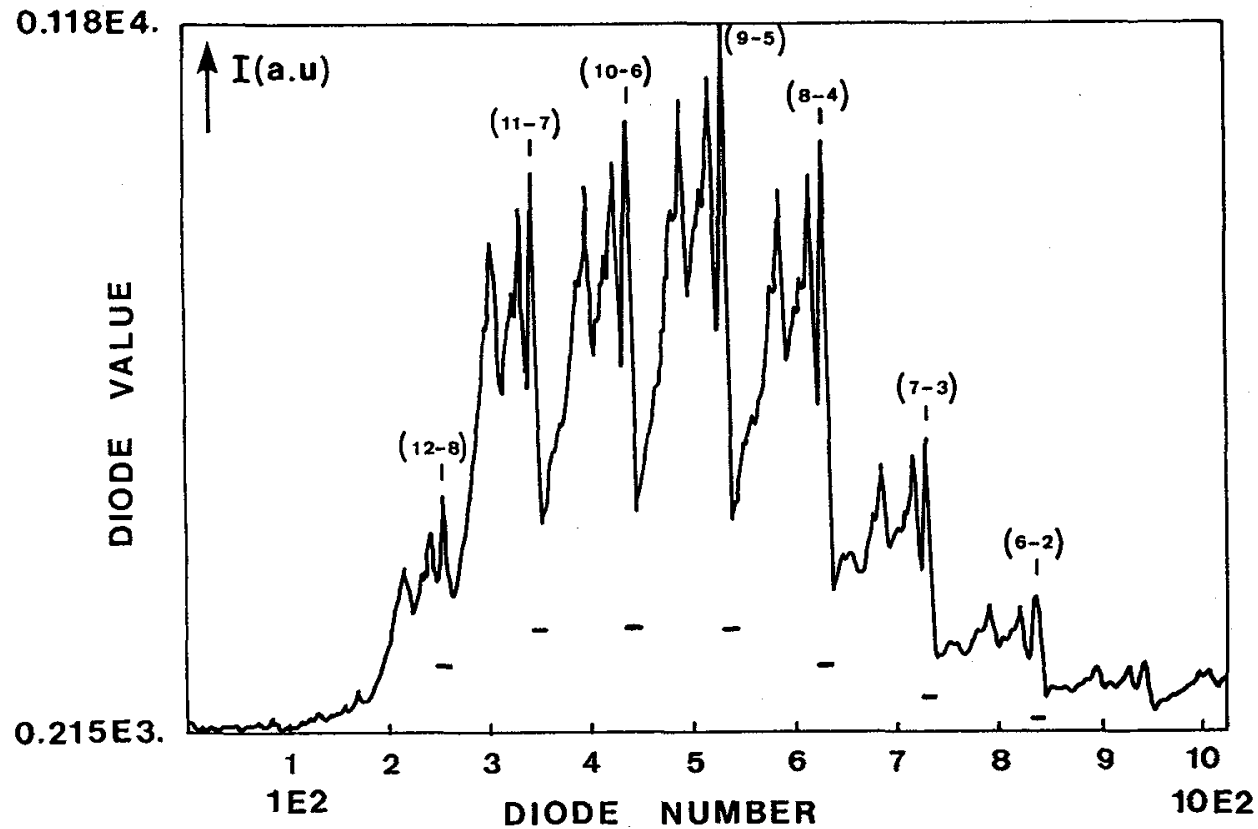

Fig. 2 - Spectrum of $N_{2} 1^{\text {st }}$ pos. in Ar-4\% $N_{2}$ post-discharge at $Z=9 \mathrm{~cm}$. $\Delta v=4$ band sequence from $\lambda=575.5 \mathrm{~nm}$. (12-8) to $\lambda=607 \mathrm{~nm}$. (6-2) with a resolution limit $\delta \lambda=0.1 \mathrm{~nm}$. Discharge surfatron $910 \mathrm{MHz}, \mathrm{p}=90 \mathrm{Torr}, 100 \mathrm{~W}, \mathrm{Q}=3 \mathrm{N \ell} \mathrm{min}^{-1}$.

The rotational structure of each vibrational band is obtained with a resolution limit of $4 \AA$. The corresponding rotational temperature is estimated to be $400( \pm 50)$ $\mathrm{K}$, keeping a nearly constant value for $\mathrm{Ar}-\mathrm{xN}_{2}$ mixtures with $\mathrm{x}=4-100 \%$ at 100 Torr and 100 watts $(6)$.

It has been observed a maximum in intensity of vibrational transitions coming from $\mathrm{N}_{2}\left(B, V^{\prime}=11\right)$ levels for pure $\mathrm{N}_{2}$ discharges. This maximum is scattered on lower levels $N_{2}\left(B, V^{\prime}=11 \rightarrow 7\right)$ in $A r-x_{2}$ with $x<10 \%$, as shown in Fig. 2 . Such a result has been previously analysed (6) as coming from recombination process i) which mainly produced $N_{2}\left(B, V^{\prime}=11\right)$ with $M_{2}=N_{2}$. In $A r-x N_{2}$ gas mixture, the $N_{2}\left(B, V^{\prime}=11\right)$ peak is progressively decreasing in front of the $\mathrm{N}_{2}\left(B, V^{\prime}=8\right)$ peak which is dominant for $A r-4 \%$ $\mathrm{N}_{2}$.

By recording the blue-violet part of the post-discharge spectrum, it has been 
observed a strong emission of $\mathrm{CN}$ radical as reproduced in Fig.3, for a $\mathrm{N}_{2} 100$ Torr, 100 . Watts, $49.5 \mathrm{MHz}$ post-discharge.

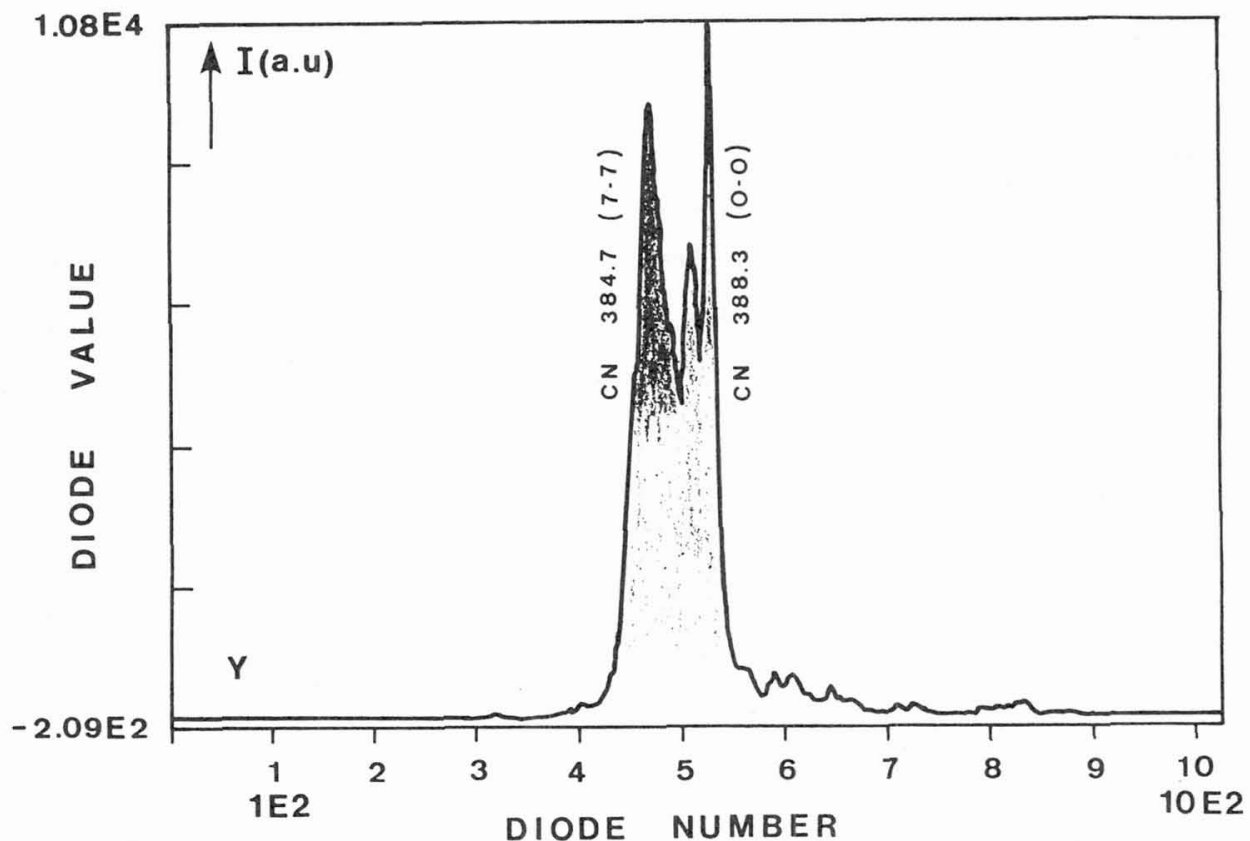

Fig. 3 - Spectrum of $C N$ violet system in $N_{2}$ post-discharge at $Z=7 \mathrm{~cm} . \Delta v=0$ band at $\lambda=388.3 \mathrm{~nm}(0,0)$ and $\lambda=384.7 \mathrm{~nm}(7,7)$ with a resolution limit $\delta \lambda=$ $0,1 \mathrm{~nm}$. Discharge Ro-box 49.5MHz, $\mathrm{p}=100 \mathrm{Torr}, 160 \mathrm{~W}, Q=2 \mathrm{~N} \ell \mathrm{min}^{-1}$.

The $\mathrm{CN}$-emission comes from $\left.\mathrm{CN}\left(\mathrm{B}^{2} \Sigma^{+}, \mathrm{V}^{\prime}\right)\right)$ excited levels. It appears in Fig. 3 a strong emission from $C N\left(B, V^{\prime}=7\right)$ near the well known emission from $C N\left(B, V^{\prime}=0\right)$. The band emission from $\mathrm{CN}\left(B, V^{\prime}=7\right)$ is produced by recombination of $N$ and $C$ atoms, following the three body reaction:

$$
C+N+M_{2} \stackrel{k_{2}}{\rightarrow} C N(B, 7)+M_{2}
$$

with $k_{2}=9.4( \pm 2.5) \times 10^{-33} \mathrm{~cm}^{6} \mathrm{~s}^{-1}$ for $M_{2}=A r-N_{2}$ as established in ref.7. Kinetics of $\mathrm{N}_{2}\left(\mathrm{~B}, \mathrm{~V}^{\prime}\right)$ and $\mathrm{CN}(\mathrm{B}, 7)$ excited states produced in the afterglow by the recombination processes $i$ ) and $i i)$ is now analysed.

4 - INTENSITIES OF $\mathrm{N}_{2}\left(\mathrm{~B}, V^{\prime}\right)$ AND CN (B, 7) RADIATIVE STATES IN THE FLOWING AFTERGLOW: DETERMINATION OF CARBON ATOM DENSITIES

The $\mathrm{N}_{2}\left(B, V^{\prime}\right)$ states are produced by reaction $\left.i\right)$ in post-discharge regime and destroyed by photon emission of frequency $\nu_{1}^{r}\left(V^{\prime}\right)$ and by the following quenching reaction: 


$$
\mathrm{N}_{2}\left(\mathrm{~B}, \mathrm{~V}^{\prime}\right)+\mathrm{M}_{2} \stackrel{\mathrm{k}_{3}}{\rightarrow} \text { products }
$$

Then the density of $\mathrm{N}_{2}\left(B, V^{\prime}\right)$ can be written as:

$$
\left[N_{2}\left(B, V^{\prime}\right)\right]=[N]^{2} \frac{\left[M_{2}\right] k_{1}\left(V^{\prime}\right)}{v_{1}^{r}\left(V^{\prime}\right)+\left[M_{2}\right] k_{3}\left(v^{\prime}\right)},
$$

where the data on $k_{1}\left(V^{\prime}\right)$ and $k_{3}\left(V^{\prime}\right)$ rate coefficients and $v_{1}^{r}\left(V^{\prime}\right)$ frequency are reproduced in ref. 6 .

As for the $C N(B, 7)$ state, it is produced by reaction $i i)$ and destroyed by radiative emission of frequency $\nu_{2}^{r}(7)$ and by the following quenching reaction:

$$
\mathrm{CN}(\mathrm{B}, 7)+\mathrm{M}_{2} \stackrel{\mathrm{k}_{4}}{\rightarrow} \text { products }
$$

It fol lows the $\mathrm{CN}(B, 7)$ density as:

$$
[C N(B, 7)]=\frac{[C][N]\left[M_{2}\right] k_{2}(7)}{\nu_{2}^{r}(7)+\left[M_{2}\right] k_{4}(7)}
$$

The radiative frequencies and quenching rates of $\operatorname{CN}(B, 7)$ are given in ref.7 and 8 , respectively.

The vibrational band intensity $I^{\prime}\left(V^{\prime}, V^{\prime \prime}\right)$ is related to the radiative state density $\left[R\left(V^{\prime}\right)\right]$ by the following equation:

$$
I\left(V^{\prime}, V^{\prime \prime}\right)=\frac{C(\lambda)}{\lambda}\left[R\left(V^{\prime}\right)\right] v^{r}\left(V^{\prime}, V^{\prime \prime}\right)
$$

where $\lambda$ is the emitted wavelength, $C(\lambda)$ is a factor related to spectral response of the detection system and $\nu^{r}\left(V^{\prime}, V^{\prime \prime}\right)$ is the transition probability.

From eq. (1-3) the intensity ratio of $\operatorname{CN}(B, 7-X, 7): I_{2}(7,7)$ and $N_{2}\left(B, V^{\prime}-A, V^{\prime \prime}\right)$ : $I_{1}\left(V^{\prime}, V^{\prime \prime}\right)$ is given by:

$$
\frac{I_{2}(7,7)}{I_{1}\left(V^{\prime}, V^{\prime \prime}\right)}=\frac{C_{2}(7,7) / \lambda_{2}(7,7)}{C_{1}\left(V^{\prime}, V^{\prime \prime}\right) / \lambda_{1}\left(V^{\prime}, V^{\prime \prime}\right)} \quad \frac{[C]}{[N]} \frac{k_{2}(7)}{k_{1}\left(V^{\prime}\right)} \frac{Q_{1}\left(V^{\prime}, V^{\prime \prime}\right)}{Q_{2}(7,7)}
$$

with $Q_{1}\left(V^{\prime}, V^{\prime \prime}\right)=\frac{v_{1}^{r}\left(V^{\prime}\right)}{v_{1}^{r}\left(V^{\prime}, V^{\prime \prime}\right)}\left(1+\frac{\left[M_{2}\right] k_{3}\left[V^{\prime}\right]}{v_{1}^{r}\left[V^{\prime}\right]}\right)$

and $Q_{2}(7,7)=\frac{v_{2}^{r}(7)}{v_{2}^{r}(7,7)}\left(1+\frac{\left[M_{2}\right] k_{4}(7)}{v_{2}^{r}(7)}\right)$.

By considering eq.4, it can be deduced the carbon atom densities from measurements of $I_{2}(7,7) / I_{1}\left(V^{\prime}, V^{\prime \prime}\right)$ and $[N]$, respectively. The $N$-atom densities have been 
determined by No titration with the experimental set up of Fig. $1(3,6)$.

After calibration the spectra response of the optical spectrometer in Fig.1 and by considering the $\lambda_{1}(9,5)$ band head in $A r-N_{2}$ gas mixtures, it has been found that:

$$
\frac{c_{2}(7,7) / \lambda_{2}(7,7)}{C_{1}(9,5) / \lambda_{1}(9,4)} \sim 1 \text { in eq. } 4 \text {. }
$$

The $Q_{1}(9,5)$ and $Q_{2}(7,7)$ terms in eq.4 are simplified with $\nu_{1}^{r}(9) \sim \nu_{1}^{r}(9,5)=$ $6.7 \times 10^{4} \mathrm{~s}^{-1}[9]$ and $v_{2}^{\mathrm{r}}(7) \sim v_{2}^{r}(7,7)=2.5 \times 10^{7} \mathrm{~s}^{-1}(7)$.

As the $k_{4}(7)$ rate coefficient is largely less than $10^{-11} \mathrm{~cm}^{3} \mathrm{~s}^{-1}(8)$, it can be deduced in $A r-N_{2}$ at $p \sim 100$ Torr that $\left[M_{2}\right] k_{4}(7)$ is less than $\nu_{2}^{r}(7)$ so that $Q_{2}(7,7) \sim 1$. Inversely $\left[M_{2}\right] k_{3}(9)$ is larger than $\nu_{1}^{r}(9)$ and eq. 4 becomes:

$$
\frac{I_{2}(7,7)}{I_{1}(9,5)}=\frac{[C]}{[N]} \frac{k_{2}(7)}{k_{1}(9)} \frac{\left[M_{2}\right] k_{3}(9)}{v_{1}^{r}(9)}
$$

In $\mathrm{Ar}-33 \% \mathrm{~N}_{2}$ gas mixture at $\mathrm{p}=100 \mathrm{Torr}\left(\mathrm{M}_{2}=3 \times 10^{18} \mathrm{~cm}^{-3}\right), k_{2}(7)=10^{-32} \mathrm{~cm}^{6} \mathrm{~s}^{-1}(7)$, $k_{1}(9)=2.6 \times 10^{-34} \mathrm{~cm}^{6} \mathrm{~s}^{-1}$ and $k_{3}(9)=2.35 \times 10^{-11} \mathrm{~cm}^{3} \mathrm{~s}^{-1}$ (cf. ref. 6 ).

Then it can be calculed:

$$
\frac{I_{2}(7,7)}{I_{1}(9,5)}=4 \times 10^{4} \frac{[\mathrm{C}]}{[\mathrm{N}]}
$$

It has been measured $[\mathrm{N}]=5( \pm 1.5) \times 10^{15} \mathrm{~cm}^{-3}$ by N0 titration and $\frac{I_{2}(7,7)}{I_{1}(9,5)} \sim 0.4$ in Ar-33\% $\mathrm{N}_{2}$ gas mixture. It results: [C] $\sim 5 \times 10^{10} \mathrm{~cm}^{-3}$.

This method has given $\mathrm{C}$-atom densities between $2 \times 10^{10}$ and $4 \times 10^{11} \mathrm{~cm}^{-3}$ in the afterglow for high percentages of $\mathrm{N}_{2}$ in Argon (33,50 and 100\%), at pressures of 100 and 200 Torr. The HF plasmas were initiated by Ro-box (13.6 and $49.5 \mathrm{MHz}$ ) and surfatron (2.45GHz) exciters (cf. Fig.1).

\section{5 - CONCLUDING REMARKS}

From the spectroscopic analysis of $A r-\mathrm{N}_{2}$ afterglows produced by $\mathrm{HF}$ discharges, the two recombination processes: $N+N+M_{2}$ and $C+N+M_{2}$, with $M_{2}=A r-N_{2}$ as a third body, have been characterized. The $N$ atom densities have been measured by $N 0$ titration and from the studiedN and $C$-atom kinetics in the post-discharge, it has been deduced the C-atom densities. This method is very sensitive for impurity detection in high pressure $(100-200 \mathrm{Torr}) \quad \mathrm{M}_{2}=\mathrm{Ar}-\mathrm{N}_{2}$ post-discharges, since $\mathrm{C} / \mathrm{M}_{2}$ ratios of $10^{-7}-10^{-8}$ have been measured. 


\section{REFERENCES}

/1/ A. RICARD, Rev. Phys. Appl. 24(1989) 251.

/2/ A.RICARD, J.E. OSEGUERA, H. MICHEL and M. GANTOIS, PSE 88, Garmish (1988) - A. RICARD, J.E. OSEGUERA, L. FALK, H. MICHEL and

M. GANTOIS, IEEE. Trans. Plasma Science (to be published 1990).

/3/ A.RICARD, A. BESNER, J. HUBERT and M. MOISAN, J. Phys. B21 (1988) L579.

/4/ M.MOISAN, Z. ZAKRZEWSKI, Rad. Process. in Disch. Plasma p.381, Ed. J.M. Proud and L.H. LUESSEN, Plenum Pub1. Corp. (1986) - J. Phys. D12 (1979) 219.

/5/ M. MOISAN, Z. ZAKRZEWSKI, US Patent App1. 903, 519 (1986).

16/ A. RICARD, H. MALVOS, M. MOISAN, J. HUBERT, 8th Symp. Elem. Process. and Chem. Reactions in Low Temp. Plasmas, Stara-Lesna (Tchecoslov. 1990) - Rapport LP 242 Orsay (1990).

/7/ N. WAHIDA, D. KLEY, K.H. BECKER and W. GROTH, J. Chem. Phys. 63 (1975) 4230.

/8/ W.M. JACKSON and J.L. FARIS, J. Chem. Phys. 56 (1972) 95.

/9/ L.G. PIPER et al., J. Chem. Phys. 90 (1989) 5337. 